\title{
'The sweeter country': social dimensions to riparian management in the Burdekin rangelands, Queensland
}

\author{
A. Lankester, P. Valentine and A. Cottrell*
}

$\mathrm{I}$ this article, we examine the social issues underpinning cattle producers' riparian management decisions in the savanna rangelands of north-eastern Queensland. Improved riparian management in these beef grazing regions has become increasingly important given the decline in water quality entering the Great Barrier Reef World Heritage Area. Consequently, there is pressure from management agencies on cattle producers to adopt recommended riparian management practices. However, little is known about what is driving cattle producers' riparian management choices and the factors influencing these choices. Interviews with producers from 18 properties in the Burdekin rangelands sought to fill this knowledge gap. Results showed that the decision by producers to adopt such riparian management practices as fencing and spelling of riparian pastures was largely based on the perceived production benefits and losses. However, an array of social, environmental and financial factors also influenced producers' riparian management decisions. Key influencing factors include social learning, position in the catchment, and financial capacity. Implications for future policy and extension programs are discussed.

Keywords: Adoption, rural landholders, water quality, beef grazing, natural resource management, decisionmaking

There is increasing concern for the condition of riparian areas $^{1}$ in the beef grazing tropical savanna rangelands of northern Queensland. Evidence suggests that poor management practices are leading to land degradation and negative impacts on in-stream and downstream water quality (Burrows 2001; Roth et al. 2002). Increased sediment and nutrient loads in run-off from beef grazing lands in catchments adjacent to the Great Barrier Reef in north Queensland are major sources of diffuse water pollutants entering the reef (Brodie \& Mitchell 2005; Haynes et al. 2007). Overgrazing is also leading to a

* Allyson Lankester, Peter Valentine and Alison Cottrell are with the School of Earth and Environmental Science, James Cook University, Townsville QLD 4814. Allyson is also with CSIRO Sustainable Ecosystems, Davies Laboratory, Townsville QLD 4814; Email: Ally.Lankester@csiro.au. decline in the productivity of riparian areas (Beare et al. 2003). This can, in turn, lead to a decline in the social wellbeing of producers and their families.

Diffuse water quality pollution is difficult to regulate as the source cannot be easily identified and quantified. The adoption of best management practices is one of the most effective ways of reducing diffuse water quality pollution levels (Ice 2004). Riparian management practices (RRMPs) recommended to improve the condition of riparian areas in the Burdekin River catchment include maintaining light stocking rates; managing for even utilisation of pasture; managing for a variable climate; spelling pasture; using appropriate fire management; maintaining vegetation groundcover to minimise gully erosion; and installing recommended fencing and water point infrastructure to manage cattle use of, and access to, the riparian zone (Coughlin et al. 2007). The advice for managing waterholes in the tropical rangelands is to exclude cattle from permanent waterholes by fencing and provide alternative water sources (Burrows 2004).

Many planning and incentive programs have been funded by the state and federal governments to encourage the voluntary adoption of such RRMPs in northern Queensland. For example, the Queensland Government's 2003 Reef Water Quality Protection Plan sought to increase the adoption of sustainable production systems through a range of incentives (Australian and Queensland governments 2004-2005). Despite these initiatives, the 2006 State of the Environment Report concluded that the need to address existing problems in regard to the state of the Great Barrier Reef remains as immediate as ever (Beeton et al. 2006).

This article - in the context of rural landholders' adoption of natural resource management practices therefore aims to increase understanding of the social dimensions underpinning riparian management in the tropical rangelands of north-eastern Australia. Reasons and perceptions behind producers' riparian management decisions and key influences on these decisions are presented. These results are followed by a discussion of the implications of this study for riparian management.

' Dixon and Douglas (2007, p. 5) defined riparian areas in the tropical savannas of Australia as 'green belts alongside creeks and rivers'. 


\section{Understanding rural landholders' adoption of natural resource management practices}

Adoption of natural resource management practices by rural landholders occurs when there is a perceived match with personal goals, which may be economic, social, cultural, spiritual or environmental (Pannell et al. 2006). When rural enterprises rely on farm income to sustain their livelihoods, economic goals figure strongly in adoption decisions (Saltiel et al. 1994; Cary \& Wilkinson 1997; Lockie \& Rockloff 2004). However, understanding rural landholders' decision-making according to economic goals becomes inadequate when the importance of financial factors in the decision-making process declines (Edwards-Jones 2006).

Adoption of natural resource management practices is also determined by perceived risks, actual risks and constraints. This is especially true in a rural industry that is subject to constant physical, economic and political fluctuations (Burton 2004). In their review of agricultural adoption research in Australia, Barr and Cary (2000) suggested that barriers to change in management practices are dominated by industrial and governmental structural factors and conditions. Many agricultural industries are financing high debts and regularly face a 'cost-price squeeze', which makes changes in individual management difficult, especially if change is perceived to be risky (Lawrence et al. 2004). Therefore, lack of financial security (whether it is perceived or actual) is a major constraint to the adoption of new practices for many rural landholders (Vanclay \& Lawrence 1995).

The adoption of riparian management practices has been the specific focus of studies in other rural regions of Australia, New Zealand and the US. In areas where farmers rely financially on produce from the land, the key influences on adoption are perceived financial benefits to adopting riparian mangement practices and compatibility of the practice with their existing context (Corbett 2002; Curtis \& Robertson 2003; Fielding et al. 2005; Bewsell et al. 2007). Conversely, intrinsic motivations for implementing RRMPS, such as desire to practice 'good' stewardship and attachment to the land, have been more prominent among landholders less reliant on the land for their income (Curtis \& Robertson 2003; Ryan et al. 2003). Exposure to information, greater knowledge of riparian management issues, and the receipt of funding has also been linked positively to the adoption of riparian management practices (Rhodes et al. 2002; Curtis \& Robertson 2003). One study in the US revealed that, while landholders recognised that there is a community responsibility to improve riparian areas, there was a denial of individual responsibility in addressing the problem (Dutcher et al. 2004). Financial constraints tend to be the main limitations that rural landholders identify in preventing the adoption of RRMP's (Rhodes et al. 2002; Curtis \& Robertson 2003). There appears, however, to be a paucity of qualitative studies that have examined social dimensions to riparian management in a tropical rangeland context.

This article explores a range of determinants of the management of riparian areas in a tropical savanna beef grazing environment.

\section{The Burdekin rangelands}

The Burdekin rangelands sub-catchment was chosen as the study area as it is within one of the 'catchment hot spots' discharging high sediment yields into the Great Barrier Reef (James Cook University 2008), and producers in this area have also participated in government-funded riparian management projects. The sub-catchment is part of the Burdekin River catchment (see Figure 1). Beef grazing is the predominant land use and most of the region is state land covered by 'pastoral holding' and 'grazing homestead' perpetual leases. More than 70 per cent of the properties are family operated, and the average time a family has managed the one property is 35 years (McCullough 2004). The Burdekin rangelands sub-catchment contributes the greatest flow of water to the Burdekin River catchment. Typically, a long dry season is followed by high rainfall events and flooding during the wet season from December to April. Terrestrial vegetation is dominated by savanna woodland with paperbarks (Melaleuca spp.) along the edge of streams.

In the Burdekin rangelands, extension activities, including the delivery of financial incentives, have been available to producers since 1994 to implement RRMPs. These programs have been mainly funded by the federal government's Natural Heritage Trust 1 and 2 programs ${ }^{2}$. From 1994 to 2004, $1782 \mathrm{~km}$ of riparian fencing and 161 off-stream water points were installed on grazing properties in the Burdekin rangelands through costsharing funding programs (Shepherd 2005). As well as these initiatives, over the last ten years, a range of other extension activities to improve riparian management (e.g research trials, demonstration sites and training courses)

${ }^{2}$ The Natural Heritage Trust (NHT) was established by the Australian Government in 1997 to help restore and conserve Australia's environment and natural resources. It has since been replaced by the Caring for Our Country initiative. 


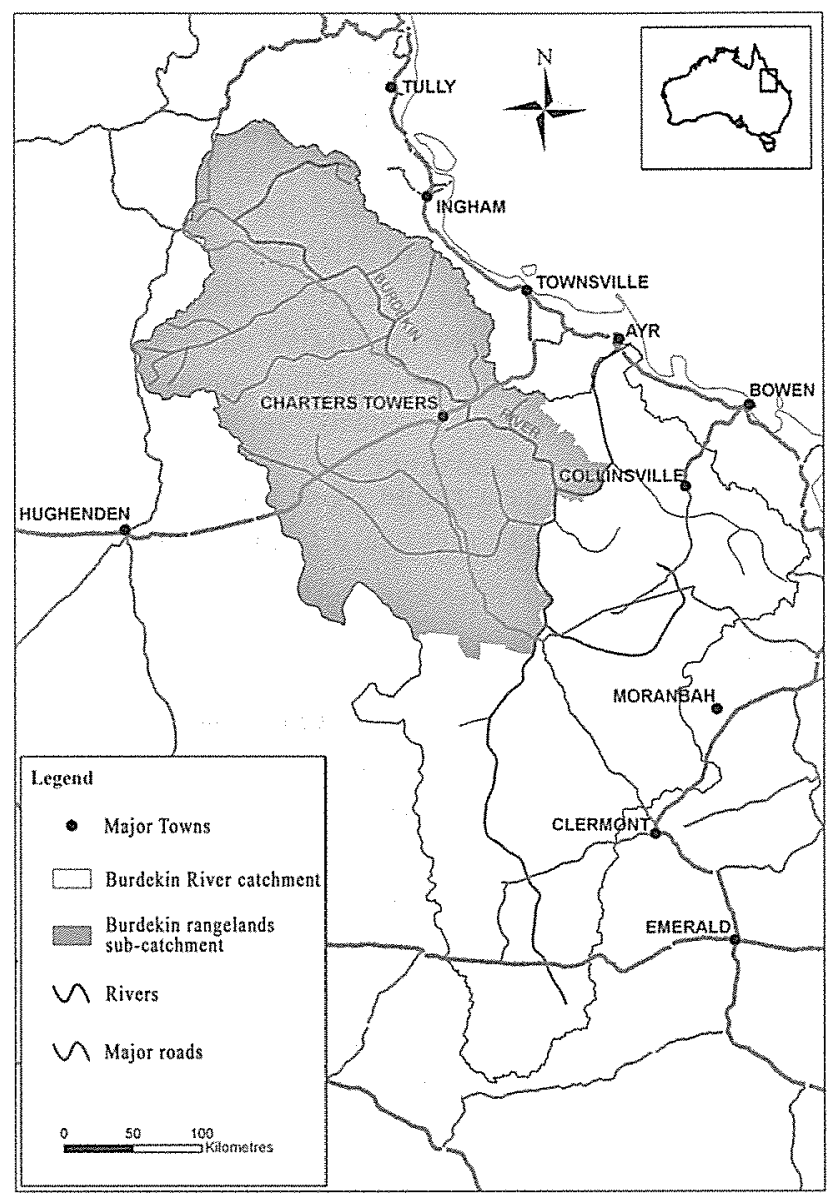

Figure 1 Map of the Burdekin rangelands sub-catchment within the Burdekin River catchment (Source: Australian Centre for Tropical Freshwater Research (James Cook University), modified by CSIRO, Townsville)

has been made available to producers in the Burdekin rangelands.

\section{Methods}

A qualitative interpretative approach was taken to investigate the social dimensions influencing riparian management decisions in the Burdekin rangelands. A qualitative approach was seen to be the most appropriate as the study was exploratory and the set of variables was largely unknown (Creswell 1994). The study sought to discover the relevant variables, not to generalise or quantify patterns.

The approach was influenced by grounded theory methods (Glaser \& Strauss 1967). Grounded theory is a way of deriving theory inductively through a continual interplay between sampling, data collection and analysis.

Purposeful and theoretical sampling strategies were used to select participants for the interviews. Purposeful sampling involves selecting participants who will provide insight and an in-depth understanding of the phenomenon (Patton 2002). Participants were chosen from a range of property sizes and from areas with different river systems (i.e. spring fed systems, the main Burdekin River channel, elevated tributaries, and floodplains). Theoretical sampling is the process of collecting information in order to refine the theoretical understandings of the research as it progresses (Creswell 1998). For this research, the economic, social, cultural, spiritual and environmental factors contributing to the adoption of riparian management were the focus.

\section{Scoping study}

Face-to-face, semi-structured interviews with open-ended questions were undertaken initially with six key informants (four 'opinion leader' participants and two government extension officers). The purpose of the interviews with these key informants was to gain a preliminary understanding of riparian management issues, practices and influential factors. These interviews informed the construction of the interview guide and the selection of the main participants.

\section{Interviews}

Face-to-face interviews with the main participants took place from January to November 2004 on the participants' properties, and lasted for three to four hours. Participants were from 18 family-operated, grazing properties where beef grazing was the main income and occupation. Eleven of the interviews were with couples. Participants were aged between 35 and 70 years and most were in the age bracket $45-60$ years. Two thirds of participants were male. The average property size was 27000 hectares.

The interview guide included open-ended questions that covered the following topics: (1) description of riparian areas; (2) perception of riparian degradation problems and issues; (3) description of riparian management practices; and (4) factors influencing riparian management decisions.

Interviews were recorded and later transcribed. Interviews ceased when no new information was being identified. Three data collection and analysis phases (four interviews in the first phase, six in the second, and eight in the last phase) took place in total. For example, following the collection and analysis of data after the second phase, it was clear that more reasoning was needed from participants in regard to their riparian management decisions. Hence, the last phase of interviewing probed participants for this reasoning. 
Table 1 Summary of the reasons that participants gave for, and for not, implementing RRMPs

\begin{tabular}{|c|c|c|}
\hline RRMPs & Reasons for adoption & Reasons for non-adoption \\
\hline \multirow[t]{7}{*}{$\begin{array}{l}\text { Fence and wet season spell } \\
\text { riparian areas }\end{array}$} & \multirow{2}{*}{$\begin{array}{l}\text { Increase quantity and quality of } \\
\text { riparian pastures to increase cattle } \\
\text { weight and quality }\end{array}$} & $\begin{array}{l}\text { No off-stream water points to } \\
\text { replace stream }\end{array}$ \\
\hline & & Water course is too small or not \\
\hline & \multirow{5}{*}{$\begin{array}{l}\text { Opportunity to trial practice before } \\
\text { full adoption } \\
\text { Increased chance of lease renewal } \\
\text { Improve water quality and the } \\
\text { ecological condition of riparian areas }\end{array}$} & permanent \\
\hline & & Need stream as a reserve water \\
\hline & & $\begin{array}{l}\text { supply if water points cease to } \\
\text { operate }\end{array}$ \\
\hline & & $\begin{array}{l}\text { Cattle access to streams can be } \\
\text { controlled by installing off-stream } \\
\text { water points alone }\end{array}$ \\
\hline & & $\begin{array}{l}\text { Difficult terrain (i.e. steep gullies, } \\
\text { anabranches and fast flowing } \\
\text { floodwaters) }\end{array}$ \\
\hline \multirow[t]{4}{*}{ Fence riparian area } & Prevent cattle accessing floodwaters & \\
\hline & $\begin{array}{l}\text { Prevent cattle accessing steep banks } \\
\text { and boggy waterholes }\end{array}$ & \\
\hline & Easier cattle mustering & \\
\hline & $\begin{array}{l}\text { Low fence maintenance after } \\
\text { flooding }\end{array}$ & \\
\hline $\begin{array}{l}\text { Maintain light stocking rate, } \\
\text { feral pig control, fence to soil } \\
\text { type, erosion control }\end{array}$ & $\begin{array}{l}\text { Increase quantity and quality of } \\
\text { riparian pastures to increase cattle } \\
\text { weight and quality }\end{array}$ & \\
\hline \multirow[t]{3}{*}{ Fire management } & \multirow{3}{*}{$\begin{array}{l}\text { Reduce fuel loads } \\
\text { Increase quantity and quality of } \\
\text { riparian pastures to increase cattle } \\
\text { weight and quality }\end{array}$} & Temporary pasture loss with low \\
\hline & & rainfall following a burn \\
\hline & & $\begin{array}{l}\text { Introduced pasture plants are fire- } \\
\text { sensitive }\end{array}$ \\
\hline \multirow[t]{2}{*}{ Install off-stream water points } & $\begin{array}{l}\text { Guaranteed water supply for cattle } \\
\text { during dry season }\end{array}$ & \\
\hline & $\begin{array}{l}\text { Increase quantity and quality of } \\
\text { riparian pastures to increase cattle } \\
\text { weight and quality }\end{array}$ & \\
\hline \multirow[t]{2}{*}{ Riparian pasture monitoring } & Increased chance of lease renewal & \\
\hline & $\begin{array}{l}\text { Improve the water quality and } \\
\text { ecological condition of riparian areas }\end{array}$ & \\
\hline \multirow[t]{4}{*}{ Weed control } & $\begin{array}{l}\text { Increase quantity and quality of } \\
\text { riparian pastures to increase cattle } \\
\text { weight and quality }\end{array}$ & $\begin{array}{l}\text { Not enough production value in } \\
\text { riparian pastures to make practice } \\
\text { worthwhile }\end{array}$ \\
\hline & Easier cattle mustering & \multirow{3}{*}{$\begin{array}{l}\text { Particular weeds are not a } \\
\text { production problem }\end{array}$} \\
\hline & Increased chance of lease renewal & \\
\hline & $\begin{array}{l}\text { Improve water quality and the } \\
\text { ecological condition of riparian areas }\end{array}$ & \\
\hline
\end{tabular}

adoption rates of RRMP's, motivations for adopting these practices, perceptions of the riparian degradation problem, and the factors influencing riparian management decisions.

\section{Definition of riparian}

The riparian area was perceived by participants as extending out to the boundaries of floodwaters (the floodplain) and encompassed the alluvial soil areas with more fertile pastures. Hence, riparian areas were often referred to as the 'sweeter country' and participants generally termed the riparian area 'river frontage'. The average width of the riparian area was said to be $1-1.5 \mathrm{~km}$ wide. The riparian areas were said to vary between four $\mathrm{km}$ in lower areas of the catchment and $100 \mathrm{~m}$ in the upper reaches.

\section{Adoption of riparian management practices}

Of the 18 properties, 12 had implemented some degree of RRMPs. These practices included fencing riparian areas parallel to the river along the boundary of the floodplain or alluvial soils, spelling at least a part of the fenced riparian area every wet season, installing offstream water points, and maintaining light stocking rates. The remaining six properties had either not

The data were analysed using the following content analysis process: (1) analysis of transcripts to form concepts; (2) coding of transcripts according to the identified concepts; (3) grouping of concepts into categories; and (4) identification of connections between categories (Strauss \& Corbin 1994).

\section{Results}

The following results include summaries of the definitions that participants gave for 'riparian', the implementèd RRMPs or had implemented general property management strategies that took some grazing pressure off riparian areas, such as installing extra water points. All properties were trying to control weeds. Fire management along riparian areas was not a common practice on the properties. Those $\mathrm{few}^{3}$ participants that said they did burn varied in their responses for the frequency and timing of burns. There were also a few properties that fenced and excluded cattle from permanent waterholes, and monitored riparian pastures using tools such as photo points and quadrant pasture sampling.

\footnotetext{
${ }^{3}$ Note: 'few' $=5-15$ per cent of participants, 'some' $=20-40$ per cent of participants, 'many' $=60-80$ per cent of participants, and 'most' $=80-90$ per cent of participants.

${ }^{4}$ Half of the Queensland rural leasehold land leases expire in the next 10-15 years and will need to be renewed under a new lease renewal strategy. The strategy has shifted from a prescriptive to a performance/ outcome-based approach to land administration, using incentives (DNR\&M 2003).
} 
Table 2 Summary of key influences on participants' riparian management

\begin{tabular}{|c|c|}
\hline Influencing factors & Influences on riparian management \\
\hline \multicolumn{2}{|l|}{ Social } \\
\hline \multirow[t]{2}{*}{ Other producers (including peers) } & Learning from seeing and hearing what others are doing \\
\hline & Concern about how others see their riparian management \\
\hline \multirow[t]{2}{*}{ Family members } & Opportunity to discuss and share decisions \\
\hline & Labour assistance \\
\hline Extension officers & Access to information, advice and funding opportunities \\
\hline \multirow[t]{2}{*}{ Extension activities (i.e. local field days) } & Source of information when making decisions \\
\hline & Learning by doing \\
\hline \multirow{6}{*}{$\begin{array}{l}\text { Catchment management groups (e.g. } \\
\text { Landcare) and training courses }\end{array}$} & Forum to share and discuss ideas, experiences and opinions \\
\hline & Increased learning and awareness of degradation problems \\
\hline & Easier problem solving \\
\hline & Encourage questioning of existing self-management practices \\
\hline & $\begin{array}{l}\text { Increase financial and management skills so that management } \\
\text { becomes less determined by external factors }\end{array}$ \\
\hline & $\begin{array}{l}\text { Create a two-way conduit for information between participants and } \\
\text { external bodies }\end{array}$ \\
\hline \multicolumn{2}{|l|}{ Property size and tenure } \\
\hline \multirow[t]{2}{*}{ Small property size } & $\begin{array}{l}\text { Limits capacity to implement riparian fencing and wet season } \\
\text { spelling and can lead to overgrazed riparian areas }\end{array}$ \\
\hline & Incentive to keep riparian areas in good condition \\
\hline New leasehold agreements & $\begin{array}{l}\text { Reluctance to outlay costs for riparian management in case of non- } \\
\text { renewal of lease (feeling of insecurity) }\end{array}$ \\
\hline \multicolumn{2}{|l|}{ Environmental } \\
\hline Drought and climate variability & Limits capacity to adopt and maintain RRMPs \\
\hline Flat, low areas & $\begin{array}{l}\text { Less susceptible to erosion and easier to install and maintain riparian } \\
\text { fencing }\end{array}$ \\
\hline Poor soil type & $\begin{array}{l}\text { Limits capacity to rehabilitate degraded areas and increases } \\
\text { susceptibility to erosion }\end{array}$ \\
\hline \multicolumn{2}{|l|}{ Financial } \\
\hline Financial constraints and debt & $\begin{array}{l}\text { Limits capacity to adopt RRMPs and can lead to overgrazed riparian } \\
\text { areas }\end{array}$ \\
\hline Financial institutions & $\begin{array}{l}\text { Lack of support to prevent overgrazing riparian areas, especially } \\
\text { during drought times }\end{array}$ \\
\hline \multirow[t]{2}{*}{ Cost-sharing funding programs } & $\begin{array}{l}\text { Accelerate the process of implementing practices where there is } \\
\text { already a plan and intention, but a lack of finances }\end{array}$ \\
\hline & A felt loss of integrity and pride, in receiving 'handouts' \\
\hline \multirow[t]{2}{*}{ Fluctuating cattle prices } & Can lead to overgrazed riparian areas \\
\hline & Increases motivation to improve the condition of riparian areas \\
\hline Increasing operational costs & Limits capacity to implement RRMPs \\
\hline
\end{tabular}

many participants said that they would not achieve production benefits without improving the condition of their riparian areas. In other words, environmental goals were seen to be entwined with achieving production goals, as expressed in the following quote:

I try to wear my two hats at all times because I'm a firm believer if you have a healthy ecosystem you are going to have a very healthy productive system ... they are invariably linked ... if you're not wearing both, your paddocks are going to suffer (P23).

\section{Perceptions of the riparian degradation problem}

While the majority of participants recognised that erosion and sediment problems in waterways were at least partially due to cattle grazing, a few participants considered the problem to be driven by non-cattle related causes or 'natural' phenomena, such as 'bigger erosion patterns' and 'big flood events'.

Can say plenty of grass helps, but if it rains hard and fast it doesn't matter ... drought and fast rain do the damage (P20).

Some participants were unconvinced that there was a sediment problem for the Great Barrier Reef resulting from upstream beef grazing activity. A few participants thought that sediment would be deposited onto

\section{Motivations for adopting riparian management practices}

Many participants said that they had adopted riparian management practices for both production and environmental reasons, but it was rare for participants to say that they had implemented practices without perceiving a private or financial benefit from doing so (see Table 1). A frequent reason that participants gave for implementing RRMPs was to 'increase [the] quantity and quality of riparian pastures to increase cattle weight and quality'. The reasons that participants gave for not implementing RRMPs were also largely based on economic and practical considerations (see Table 1); downstream areas before it reached the Great Barrier Reef. Some participants were also sceptical or unsure of the credibility of scientific findings that sediment and nutrient run-off from grazing lands is having an impact on the Great Barrier Reef.

Some scientists are going in boots and all talking about all the damage that's been done. Other's are saying just the opposite...our reefs are the best in the world. So I don't know really...a fair bit of it's political really (P5).

Most participants said that they perceived erosion, caused by the compaction of soil during cattle movement, to be the main impact on riparian areas from cattle grazing. 
However, many of the participants thought that the damage caused by feral pigs and woody weed species was more of a riparian degradation problem than problems caused by cattle grazing. Furthermore, some participants believed that sediment run-off from soil erosion originated more from higher elevated paddocks than from riparian areas.

\section{Influences on riparian management decisions}

Participants were asked what factors influenced their riparian management decisions, positively and negatively. An array of factors influenced the riparian management decisions of participants; in particular, their capacity and propensity to implement RRMPs (see Table 3). Social interaction with other producers and extension officers, especially in situations where practical learning occurred, was a particularly strong factor with positive influence over participants' riparian management decisions.

\section{Discussion}

The results of this study suggest that the adoption of RRMPs by cattle producers in the savanna rangelands of north-eastern Australia could be accelerated if RRMPs are perceived as beneficial for production. This finding compares with other studies that have investigated the adoption of best management practices by rural landholders (Curtis \& Robertson 2003; Lockie \& Rockloff 2004; Bewsell et al. 2007). RRMPs that were perceived to increase pasture and cattle production, such as fencing and spelling riparian pastures, were more readily adopted by participants than those practices that were perceived to have less production benefit (i.e. fire management and the permanent exclusion of cattle from waterholes). The practice of fencing and wet season spelling of riparian areas was seen by participants to be particularly beneficial for production in the lower areas of the Burdekin rangelands where the most productive pastures are wide floodplain areas. The relative advantage and 'trial-ability' of RRMPs also contributed to the perceived production benefits of RRMPs; this agrees with the conclusions made by Pannell et al. (2006). Where beef production is the main land use and sole income source for producers, it appears necessary that riparian management decisions be seen through a production lens.

Participants perceived that, if they were not achieving environmental goals, they would not be achieving production goals in their riparian management. Greiner et al. (2003), in their survey of rural landholders in the Burdekin River catchment, also found that landholders expressed a large degree of congruence between environmental and production goals. This coupling of goals also supports the conclusion by Vanclay (2004, p. 214), that 'farmers do not distinguish environmental issues from other farm management issues'. However, rural landholders' understanding of 'conservation' is often framed within an agricultural discourse whereas scientists are more likely to encompass concepts such as biodiversity in their understanding of 'conservation'. Further exploration of knowledge differences between producers and management agencies appears necessary to forge an improved, two-way understanding of riparian management issues to help accelerate the adoption rates of RRMPs.

Differences in goals and intentions among management agencies and producers suggest that more attention may need to be given to monitoring the ecological outcomes of implemented RRMPs. If RRMPs are applied with low 'scientific' environmental objectives or principles, they could be making little difference to improving land degradation and water quality problems. For example, inappropriate management of off-stream water points, especially in habitat that has previously not had grazing pressure, has been found to lead to biodiversity loss (Landsberg et al. 1997; Ludwig et al. 1999); and native vegetation and stream biota along riparian areas have been shown to have a low resilience to frequent and intense fires (Anderson et al. 2005; Radford et al. 2008). More extensive monitoring and evaluation of implemented RRMPs to know what is working and where would assist producers to make more informed decisions, and management agencies to make more efficient policy decisions. Collaboration between producers and research agencies in the design and administration of a monitoring program would be appropriate.

The results of this study also suggest that specific practices are not always suitable for all areas. Therefore, recommending riparian management 'principles', rather than specific 'practices', would be a more suitable management approach. Such an approach would ensure that principles (i.e. maintaining a minimum level of vegetation groundcover along riparian areas) guide the selection of management practices. For example, to achieve an adequate percentage of groundcover in hilly terrain (i.e. the principle), it may be more feasible for a producer to maintain light cattle stocking rates and wet season spelling paddocks than to fence riparian areas (i.e. the practices). The current developers of best management practice recommendations for grazing lands of the Burdekin River catchment through the regional Water Quality Improvement Plan are applying such an approach (see Coughlin et al. 2007). 
The range of social, environmental and financial influences on producers' riparian management decisions suggests that a mix of policy incentives and initiatives would be a suitable policy design to encourage improved riparian management. Other evidence also suggests that landholders in the Burdekin River catchment have preference for a suite of incentives to encourage adoption of best management practices to improve water quality (see Lankester \& Greiner 2007). A mix of incentives to increase adoption rates would include a combination of financial incentives, education and awareness activities, and regulation.

Extension activities focused on enhancing knowledge and skills through practical social interactions with others in the industry were a strong positive influence on the participants' riparian management decisions. Learning through active participation in informal, practical and pervasive social interactions has been shown elsewhere to shape rural landholder behaviour (Leeuwis 2004; Allan 2005). Therefore, providing more information to producers about riparian management in a practical social learning context is likely to accelerate adoption rates of recommended practices. More information about the benefits of practices that appear to have low adoption rates, such as permanent exclusion of cattle from waterholes and appropriate fire management, could increase their adoption rates. In addition, information and training on indicators of riparian health and on financial management skills may lead to improved riparian management. Increased skills in financial management, for example, may reduce the financial uncertainty for producers associated with external conditions (e.g. climate variability and fluctuating cattle prices) so that RRMPs are seen to be more viable. On the other hand, increased information for producers on the signs of riparian health should allow producers to make more informed riparian management decisions.

In addition, regulation that is designed collaboratively with producers would be an important element in a mix of policy initiatives to encourage improved riparian management. The new leasehold renewal strategy in Queensland (State of Queensland 2007) appears, from the results of this study, to be providing an incentive for some producers to implement RRMPs. The recent announcement by the Queensland Government (2008) that it will regulate polluting practices, such as overgrazing in catchments adjacent to the Great Barrier Reef, may be a step in this direction.

\section{Conclusion}

Reducing diffuse water quality pollution entering the Great Barrier Reef from grazing lands in north-eastern Queensland is a major priority for management agencies. This study provides a detailed view of how cattle producers from 18 properties in the Burdekin rangelands are managing riparian areas and why. Results suggest that the adoption of RRMPs will be slow if producers cannot see production benefits from adopting these practices. While producers remain within a production-based land management culture, it makes sense that those practices that fit within this culture and that are cost-effective will be more readily adopted. Given that production goals are important drivers of riparian management, more attention may need to be given to measuring the ecological and water quality outcomes of implemented practices. Increased monitoring will also give further credibility to the use of these practices by producers. The diversity of situations among producers suggests that recommending principles to improve riparian management, rather than promoting specific practices, would be the best management approach. Given the range of influences on producers' riparian management decisions, a mix of policy initiatives to accelerate adoption rates would be most appropriate. Incentives that reward producers for improved riparian management and extension activities that involve learning through practice-based social interactions - that are designed and implemented collaboratively - would be important policy initiatives to encourage improved riparian management.

\section{Acknowledgments}

The authors thank the landholders who participated in this study and Samantha Stone-Jovicich and Ian Dixon for their reviews of manuscript drafts. The Tropical Savannas CRC, Land and Water Australia, the Australian Centre for Tropical Freshwater Research and James Cook University funded the postgraduate research on which this article is based. Thanks also to Mark Fenton for his early supervision of the research and the reviewers and editors of this journal for particularly helpful comments.

\section{References}

Allan, J 2005, 'Farmers as learners: Evolving identity, disposition and mastery through diverse social practices', Rural Society, vol. 15, pp. 4-21.

Anderson, AN, Cook, GD, Corbett, LK, Douglas, MM, Eager, RW, Russell-Smith, J, Setterfield, SA, Williams, RJ \& Woinarski, JCZ 2005, 'Fire frequency and biodiversity conservation in Australian tropical savannas: Implications from the Kapalga fire experiment', Austral Ecology, vol. 30, pp. 155167. 
Australian and Queensland governments 2004-2005, Reef Water Quality Protection Plan annual report, Queensland Government, Brisbane.

Barr, N \& Cary, J 2000, Influencing improved natural resource management on farms: A guide to understanding factors influencing the adoption of sustainable resource practices, Bureau of Rural Sciences, Canberra.

Beare, S, Bell, R, Blias, R, Gooday, P, Heaney, A, Hooper, S, Langenkamp, D, Love, G, Levantis, C, Qureshi, E \& Riley, C 2003, Natural resource management in the Burdekin River Catchment: Integrated assessment of resource management at the catchment scale- a case study, ABARE, Canberra.

Beeton, RJS, Buckley, KI, Jones, GJ, Morgan, D, Reichelt, RE \& Trewin, D 2006, Australia State of the Environment: Independent report to the Australian Government Minister for the Environment and Heritage, Department of the Environment, Water, Heritage and the Arts, Canberra, viewed 9 January 2008, $<$ http://www.environment.gov.au/soe/2006/publications/report/ coasts-3.html>.

Bewsell, D, Monaghan, RM \& Kaine, G 2007, 'Adoption of stream fencing among dairy farmers in four New Zealand catchments', Environmental Management, vol. 40, pp. 201-209.

Brodie, JE \& Mitchell, AW 2005, 'Nutrients in Australian tropical rivers: Changes with agricultural development and implications for receiving environments', Marine Freshwater Research, vol. 56, pp. 279-302.

Burrows, D 2001, 'Livestock management in streams and wetlands: Examples from the Burdekin catchment, North Queensland', in B Myers, M Mckaige, P Whitehead \& M Douglas (eds), Wise use of wetlands in northern Australia: Grazing management in wetlands and riparian habitats, Centre for Tropical Wetlands Management, Northern Territory University, Darwin, pp. 17-19.

Burrows, D 2004, 'Aquatic ecosystems', in M Mccullough \& B Musso (eds), Healthy rangelands: Principles for sustainable systems. Focus on Australia's Burdekin rangelands, Tropical Savannas CRC, Darwin, pp. 147-170.

Burton, RJF 2004, 'Reconceptualising the 'behavioural approach' in agricultural studies: A socio-psychological perspective', Journal of Rural Studies, vol. 20, pp. 359-371.

Cary, JW \& Wilkinson, RL 1997, 'Perceived profitability and farmers' conservation behaviour', Journal of Agricultural Economics, vol. 48, pp. 13-21.

Corbett, JB 2002, 'Motivations to participate in riparian improvement programs: Applying the theory of planned behavior', Science Communication, vol. 23, pp. 243-263.

Coughlin, T, Nelson, B \& O'Reagain, P 2007, Grazing land best management practices (BMPs) draft guidelines, Burdekin Solutions Ltd., Townsville, Qld.

Creswell, JW 1994, Research design: Qualitative and quantitative approaches, Sage, Thousand Oaks, California.

Cresswell, JW 1998, Qualitative inquiry and research design: Choosing among five traditions, Sage, Thousand Oaks, California.
Curtis, A \& Robertson, A 2003, 'Understanding landholder management of river frontages: The Goulburn Broken', Ecological Management and Restoration, vol. 4, pp. 45-54.

Dixon, I \& Douglas, M 2007, A field guide to assessing Australia's tropical riparian zones, Tropical Savannas Cooperative Research Centre, Darwin.

DNR\&M (Department of Natural Resource and Mines) 2003, Draft state rural leasehold land strategy, DNR\&M, Brisbane.

Dutcher, D, Finley, J, Luloff, AE \& Johnson, J 2004 , 'Landowner perceptions of protecting and establishing riparian forests: A qualitative analysis', Society and Natural Resources, vol. 17, pp. 329-342.

Edwards-Jones, G 2006, 'Modelling farmer decision-making: Concepts, progress and challenges', Animal Science, vol. 82, pp. 783-790.

Fielding, KS, Terry, DJ, Masser, BM, Bordia, P \& Hogg, MA 2005, 'Explaining landholders' decisions about riparian zone management: The role of behavioural, normative, and control beliefs', Journal of Environmental Management, vol. 77, pp. 12-21.

Glaser, B \& Strauss, AL 1967, The discovery of grounded theory: Strategies for qualitative research, Aldine Pub. Co., Chicago.

Greiner, R, Stoeckl, N, Stokes, C, Herr, A \& Bachmaier, J 2003, Natural resource management in the Burdekin Dry Tropics: Social and economic issues, CSIRO Sustainable Ecosystems, Townsville, Qld.

Haynes, D, Brodie, J, Waterhouse, J, Bainbridge, Z, Bass, D \& Hart, B 2007, 'Assessment of the water quality and ecosystem health of the Great Barrier Reef (Australia): Conceptual models', Environmental Management, vol. 40, pp. 993-1003.

Ice, G 2004, 'History of innovative best management practice development and its role in addressing water quality limited bodies', Journal of Environmental Engineering, vol. 130, pp. 684-689.

James Cook University (JCU) 2008, Catchment hotspots deliver nutrients to the reef, JCU, Townville, Qld, viewed 3 March 2009, <http://www.Jcu.Edu.Au/Research/Excellence/ Jcuprd_036937.html >.

Landsberg, J, James, CD, Morton, SR, Hobbs, TJ, Stol, J, Drew, A \& Tongway, H 1997, The effects of artificial sources of water on rangeland biodiversity. Final report to the Biodiversity Convention and Strategy Section of the Biodiversity Group, Environment Australia, Environment Australia and CSIRO, Canberra.

Lankester, A \& Greiner, R 2007, Developing appropriate incentives for improving water quality in the Burdekin river catchment, in AL Wilson, RL Dehaan, RJ Watts, KJ Page, KH Bowmer \& A Curtis (eds), Fifth Australian Stream Management Conference. Australian rivers: Making a difference, Charles Sturt University, Thurgoona, NSW.

Lawrence, G, Richards, CA \& Cheshire, L 2004, 'The environmental enigma: Why do producers professing stewardship continue to practise poor natural resource 
management?' Journal of Environmental Policy and Planning, vol. 6, pp. 251-270.

Leeuwis, C 2004, Communication for rural innovation: Rethinking agricultural extension, Blackwell Science Ltd, Oxford.

Lockie, S \& Rockloff, S 2004, Landowner attitudes to wetlands and wetland conservation programs and incentives, Report to the Commonwealth Department of Environment and Heritage, Cooperative Research Centre for Coastal Zone, Estuaries and Waterway Management, Brisbane.

Ludwig, JA, Eager, RJ, Williams, RJ \& Lowe, LM 1999, 'Declines in vegetation patches, plant diversity, and grasshopper diversity near cattle watering-points in the Victoria River District, Northern Australia', Rangeland Journal, vol. 21, pp. 135-149.

McCullough, M 2004, 'Snapshot of the upper Burdekin Rangelands', in M Mccullough \& B Musso (eds), Healthy rangelands: Principles for sustainable systems. Focus on Australia's Burdekin rangelands, Tropical Savannas CRC, Darwin, pp. 1-10.

Pannell, DJ, Marshall, GR, Barr, N, Curtis, A, Vanclay, F \& Wilkinson, R 2006, 'Understanding and promoting adoption of conservation technologies by rural landholders', Australian Journal of Experimental Agriculture, vol. 46, pp. 1407-1424.

Patton, MQ 2002, Qualitative research and evaluation methods, Sage, Thousand Oaks, California.

Queensland Government 2008, Premier warns of chemical danger to the Great Barrier Reef, Queensland Government, Brisbane, viewed 12 May 2009, <http://www.cabinet. qld.gov.au/MMS/StatementDisplaySingle.aspx?id=61053>.

Radford, IJ, Grice, AC, Abbott, BN, Nicholas, M \& Whiteman, L 2008, 'Impacts of changed fire regimes on tropical riparian vegetation invaded by an exotic vine', Austral Ecology, vol. 33, pp. 151-167.

Rhodes, HM, Leland, LS \& Niven, BE 2002, 'Farmers, streams, information, and money: Does informing farmers about riparian management have any effect?' Environmental Management, vol. 30, pp. 665-677.

Roth, CH, Lawson, G \& Cavanagh, D 2002, Overview of key natural resource management issues in the Burdekin catchment, with particular reference to water quality and salinity: Burdekin condition study phase 1, Burdekin Dry Tropics Board, Townsville, Qld.

Ryan, RL, Erikson, DL \& De Young, R 2003, 'Farmers' motivations for adopting conservation practices along riparian zones in a mid-western agricultural watershed', Journal of Environmental Planning and Management, vol. 16, pp. 19-37.

Saltiel, J, Bauder, JW \& Palakovich, S 1994, 'Adoption of sustainable agricultural practices: Diffusion, farm structure, and profitability', Rural Sociology, vol. 59, pp. 333-349.

Shepherd, B 2005, To stand still is to go backwards: Effective NRM extension in the Burdekin Rangelands, in T Graham, $\mathrm{J}$ James, A Leach \& A Moore (eds), Building capacity for sustainability resource management...moving a wheelbarrow full of frogs, Proceedings of the Natural Resource Management
Extension Symposium, The Regional Institute Limited, Toowoomba, QId.

Strauss, A \& Corbin, J 1994, 'Grounded theory methodology: An overview', in NK Denzin \& YS Lincoln (eds), Handbook of qualitative research, Sage, Thousand Oaks, California, pp. 273285.

The State of Queensland 2007, State rural leasehold land strategy, Department of Natural Resources and Water, Brisbane.

Vanclay, F 2004, 'Social principles for agricultural extension to assist in the promotion of natural resource management', Australian Journal of Experimental Agriculture, vol. 44, pp. 213-222.

Vanclay, F \& Lawrence, G 1995, The environmental imperative: Eco-social concerns for Australian agriculture, Central Queensland University Press, Rockhampton, Qld. 